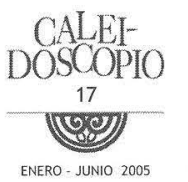

\title{
SEIS APLICACIONES DE LA HERMENÉUTICA ANALÓGICA
}

VÍCTOR HUGO SALAZAR ORTIZ

Departamento de Filosofía/UAA

Enrique Luján Salazar (comp.), Interpretación, analogía y realidad. Diálogos con Mauricio Beuchot, Universidad Autónoma de Aguascalientes, Aguascalientes, 2004.

L a actualización permanente de los docentes de todo nivel educativo debe ser una constante y ésta debe asumirse responsablemente, tanto de manera personal, como comunitaria mediante un diálogo entre los académicos de la institución, así como con los de otras instituciones. Muestra de esto es el libro Interpretación, analogía y realidad, en el cual se exponen los trabajos finales de algunos de los participantes (profesores del Centro de Ciencias Sociales y
Humanidades de la Universidad Autónoma de Aguascalientes), en el seminario de Ontología contemporánea impartido por Mauricio Beuchot, prestigiado catedrático del Instituto de Investigaciones Filológicas de la unAm.

El texto Interpretación, analogía y realidad está conformado por seis trabajos: en los dos primeros se elabora un desarrollo teórico de la hermenéutica analógica y las implicaciones que ésta tiene en la interpretación de los textos; en los dos siguientes se analiza, respectivamente, la relación existente entre la hermenéutica analógica con la filosofía de la ciencia y la literatura; en los trabajos restantes se intenta mostrar la aplicabilidad metodológica de la hermenéutica analógica más allá 
del texto, tratando de encontrar el ser pragmático de la misma y su viabilidad en la esfera humana.

Juan José Láriz Durón en su trabajo "Relación entre metafísica y hermenéutica" sostiene la importancia de recuperar en la actualidad la propuesta hermenéutica hecha en el siglo xIx, ya que más allá de ser un método filosófico nos involucra en un re-descubrimiento significativo del hombre, del mundo y de su historia, lo cual nos permite una mayor y mejor comprensión de los hechos y de nosotros mismos. A esta propuesta se suma, la hermenéutica analógica la cual permite abarcar los variados sentidos polisémicos de las interpretaciones, evitando con ello el univocismo y la interpretación cerrada; sin embargo, debe evitarse caer en el equivocismo, para lo cual es necesario que el lector capte lo que el autor quiso decir descifrando el código significativo utilizado por éste. El cumplimiento de este objetivo sólo se consigue cuando "texto, autor e intérprete (lector) son agentes de una contextuación", señala el autor. Por último, establece la mutua relación que guardan la metafísica y la hermenéutica, ya que entre ellas existe una "relación recíproca en el sentido en que la metafísica como apertura del ser, puede interpretar-comprender al mundo gracias a la comprensión hermenéutica histórico-lingüística que se suscita a nuestro alrededor". Así es que más que una anulación de una o de otra existe una mutua complementariedad entre ambas.

En el trabajo de Ernesto Martínez Arenas titulado "Metafísica, ontología y hermenéutica" se enfatiza el hecho de que los filósofos contemporáneos, más allá de desarrollar una filosofía basada en fundamentos metafísicos, pretenden elaborar sus juicios e ideas basados en argumentos ontológicos. "Hoy se aborda la comprensión del mundo desde la multiplicidad ontológica, no desde la unicidad metafísica". Señala también que la filosofía contemporánea es netamente antropológica y dentro de ella se ha enfatizado el problema del lenguaje. La primera dificultad con la que se encuentra dicho conflicto es que el lenguaje, analizado desde la hermenéutica, no es unívoco sino polisémico, lo cual nos puede conducir hacia el equivocismo o univocismo, por lo que necesitamos un método mediador que nos permita evitar la confrontación entre la unilateralidad y la pluralidad, y éste 
lo proporciona la hermenéutica analógica. A través de ella se pretende llegar al acuerdo mediante la superación de los posibles errores de la interpretación. Este método, abre la puerta al hombre particular para asumirse él mismo, como responsable de su existencia individual y social por medio del diálogo personal y trascendente.

El trabajo de José de Lira Bautista, titulado "Conocimiento y realidad en el realismo trascendental de Roy Bhaskar", nos ofrece una visión bastante amplia de este filósofo, quien propone que la filosofía de la ciencia debe apoyar y reconciliar dos aspectos paradójicos de la ciencia: su carácter social, fruto de la producción del conocimiento humano (dimensión transitiva), y el criterio denominado realismo estructural, el cual es independiente de la actividad del hombre (dimensión intransitiva). La función de la filosofía de la ciencia, de acuerdo con este autor, consiste, en reconciliar la actividad de la ciencia como proceso transitivo, producto de la actividad humana, con la dimensión intransitiva del mundo, que no depende ni del conocimiento ni de los hombres. Para la elaboración de este estudio, Bhaskar analiza tres tradiciones en la filo- sofía de la ciencia: el empirismo clásico, el idealismo trascendental y el realismo trascendental. José de Lira en su trabajo hace un breve análisis del estudio que Bhaskar elabora de ellas y, finaliza el mismo, comparando sus conclusiones con otros tipos de realismo, ya señalados por él al inicio de su trabajo y que son el realismo interno de Hillary Putnam y el aristotélico-tomista de Mauricio Beuchot.

Jorge Ávila Storer parte de la idea de "juego" propuesta por Gadamer para una hermenéutica de la obra de arte para presentar el trabajo "Tres intérpretes del juego: Hans-Georg Gadamer, Ernesto Sábato y Julio Cortázar". El objetivo en este análisis es mostrar como las ideas lúdicas de Gadamer no son capaces de explicar las imágenes que pro porciona la literatura de algunos escritores del siglo xx, más específicamente de Julio Cortázar y Ernesto Sábato. Jorge Ávila analiza los principales principios del juego propuestos por Gadamer, entre los cuales destaca los siguientes: sirve para "distraerse", requiere "falta de esfuerzo", es un "escape de la rutina", tiene una "demarcación propia", se necesita de "otro" para jugar. Este último elemento del jueg, es el más im- 
portante, pues en él es en donde propiamente se da la "fusión de horizontes", y en el caso concreto de la obra, entre arte y lector. A través de un análisis detallado expone el desarrollo literario de las obras de Sábato y Cortázar, y muestra cómo se da el "juego" en ellas, y mediante éste, establece algunas relaciones con las creaciones literarias de algunos de sus contemporáneos y de los clásicos. Para el autor, las ideas de Gadamer son válidas sólo en determinados contextos e incluso no en todas la situaciones, como sería el momento actual. La propuesta gadameriana se aplica de manera más clara en la obra de arte del pasado, debido básicamente a que las reglas del juego eran más claras, eran estables. En la actualidad todo es "efímero", el ser humano actual ya no es parte de la comunidad humana, se vive una vida fragmentada, el juego se torna confuso y éste ha llegado incluso a "pervertirse". Las reglas del juego están en crisis y, con esto, las imágenes literarias del presente.

Patricia Patiño en su trabajo "Posibilidades de la hermenéutica analógica en la ontología de la educación" elabora una analogía, partiendo del libro Virtudes, valores y educación de Samuel Arriarán, entre
La Universidad Pedagógica Nacional y la Universidad Autónoma de Aguascalientes, siguiendo como línea medular la pregunta "¿cuál es la concepción de la educación en nuestro país?", a la que da respuesta a través de dos reflexiones: el malestar de la educación y reorientando la educación. En la primera, señala como principal problema educativo la "pérdida" de valores en el proceso de enseñanza- aprendizaje, para lo cual las instituciones implementan diver sos cursos polifacéticos de ética. Mediante éstos, intentan subsanar dicha "pérdida", la cual obedece, en cierto sentido, al asunto de la globalización y los tratados de libre comercio, que exigen, más que vocación, eficiencia. Una prueba de esto, es que los cursos para profesores, más que servir para actualizar su formación, sólo sirven para elevar sus puntajes en los programas de evaluación nacionales. En la segunda reflexión hace un llamado para que las universidades contemplen los objetivos de los programas centrales, así como los requerimientos y demandas locales. Esto se logrará sólo mediante el diálogo en la era de la comunicación, ya que éste debe ayudar a crear los programas que conformen el verdadero ser de la educación en nuestro país. 
El último trabajo de esta antología corresponde a María del Carmen Platas Pacheco quien nos presenta "La analogía como método de predicación jurídica a la luz de la tradición clásica". Ella analiza el desarrollo significativo del concepto analogía a través de la historia y, más específicamente, en el ámbito jurídico. Señala que este concepto, en el caso de la predicación jurídica tiene dos acepciones: analogía proporcional y analogía por atribución. El primero de ellos indica que hay un orden de justicia establecido por naturaleza, el segundo está orientado hacia un orden pactado. Señala, además, que este último tomó vigencia a partir del siglo xvi, haciendo que el de proporcionalidad perdiera su valor y fundamentación metafísica. Frente a esto, nos muestra en su trabajo la insuficiencia de los sistemas jurídicos modernos y la necesidad de volver a la predicación clásica de justicia.

La diversidad de temas tratados en este libro permitirá a todo lector encontrarse con un método filosófico abierto a la interpretación y al diálogo constructivo, como hemos tratado de mostrarlo en estas líneas, y mediante él se da cumplimiento a uno de los deberes principales de la filosofía que es el discurrir constante. 
